\title{
PENGEMBANGAN PROGRAM KEGIATAN PEMBIASAAN BERBASIS TQM DI RAUDHATUL ATHFAL (RA)
}

\author{
Novan Ardy Wiyani \\ Institut Agama Islam Negeri (IAIN) Purwokerto \\ E-mail: fenomenajiwa@gmail.com
}

Article received: 20 Januari 2017 Review process: 03 Februari 2017

Article published: 28 Februari 2017

\begin{abstract}
Abstrak
Tulisan ini ditujukan untuk mendapatkan langkah-langkah dalam pengembangan kegiatan pembiasaan bagi anak usia dini berbasis TQM di Raudhatul Athfal (RA). Ada delapan langkah dalam pengembangan kegiatan pembiasaan bagi anak usia dini berbasis TQM. Pertama, melakukan analisis SWOT. Kedua, membuat kebijakan RA yang fokus pada pembentukan karakter anak usia dini. Ketiga, merumuskan visi, misi, tujuan, dan nilai-nilai yang fokus pada pembentukan karakter anak usia dini. Keempat, membuat jaminan mutu lulusan RA. Kelima, menentukan strategi pencapaian jaminan mutu lulusan RA. Keenam, menentukan kegiatan pembiasaan untuk mencapai indikator pada setiap kompetensi di jaminan mutu lulusan RA. Ketujuh, membuat SOP setiap bentuk kegiatan pembiasaan. Kedelapan, melakukan kegiatan supervisi untuk memastikan bahwa jalannya kegiatan pembiasaan sesuatu dengan SOP.
\end{abstract}

Kata kunci: pembiasaan, TQM, RA.

\section{A. PENDAHULUAN}

Pada masa kini mulai terjadi pergeseran paradigma pada para orang tua terkait dengan potret ideal seorang anak. Jika dulu mereka menginginkan memiliki anak yang cerdas intelektualnya, namun kini mereka mulai mengingin memiliki anak yang cerdas spiritualnya. Tentunya pergeseran paradigma ini bukannya tanpa sebab. Ada empat faktor determinan terkait dengan pergeseran tersebut.

Pertama, orang tua mulai sadar betul bahwa anak adalah investasi bagi mereka bukan hanya di dunia tetapi juga di akherat. Hal itu menjadikan orang tua menginginkan agar anaknya menjadi anak yang sholeh/sholehah. Pada dasarnya anak yang sholeh/sholehah adalah anak yang memiliki kecerdasan spiritual. Kedua, orang tua mulai gelisah melihat berbagai fakta yang terjadi di lingkungan sekitar terkait dengan semakin merosotnya moralitas masyarakat. Berbagai kasus yang menunjukkan semakin merosotnya moralitas masyarakat bisa dengan mudah ditemui di berbagai pemberitaan pada media massa. 
Ketiga, orang tua mulai mewaspadai dampak negatif yang ditimbulkan dari era komunikasi berbasis internet. Kini media sosial seperti facebook dan twitter bisa dengan mudah menjadikan seorang anak memiliki kepribadian ganda. Pada dunia nyata anak menjadi pribadi yang penurut, namun di dunia maya anak menjadi pribadi yang suka mencela, menghina, menghujat, bahkan menebarkan kebencian. Tidak menutup kemungkinan sikapnya di dunia maya tersebut dapat mempengaruhi sikapnya di dunia nyata. Keempat, orang tua mulai berpikir di zaman sekarang saja kehidupan semakin menantang dan tidak bisa diprediksi, apalagi di zaman kehidupan anaknya kelak ketika mereka dewasa. Orang tua mulai takut jika kelak anaknya menjadi manusia dewasa yang tidak berkarakter, yang mudah diombang-ambing oleh kehidupan dunia yang penuh tantangan dan penuh dengan ketidakjelasan.

Tentunya jika digali lebih radiks dan komprehensif dapat ditemukan lagi faktor-faktor determinan yang mengakibatkan pergeseraan paradigma pada diri orang tua. Lembaga pendidikan pun harus merespon pergeseran paradigma tersebut. Diakui atau pun tidak lembaga pendidikan menjadi pihak yang ikut menentukan bagaimana potret ideal seorang anak. Apakah lembaga pendidikan akan melahirkan lulusan anak yang cerdas intelektualnya?, ataukah lembaga pendidikan akan melahirkan lulusan anak yang cerdas spiritualnya?.

Jika kedua pertanyaan itu dihadapkan dengan hasil penelitian Danar Johar dan Ian Marshal terkait dengan kecerdasan spiritual (spiritual quotient) serta hasil penelitiannya Daniel Goleman terkait dengan kecerdasan emosional (emotional quotient), maka idealnya lembaga pendidikan dapat meluluskan anak didik yang cerdas spiritual. Jika anak cerdas spiritualnya maka ia juga akan memiliki kecerdasan intelektual. Kesuksesan anak di kehidupan dunia dan akherat sangat ditentukan oleh kecerdasan spiritualnya, bukan kecerdasan intelektualnya.

Hal tersebut menjadikan optimalisasi kecerdasan spiritual anak menjadi sesuatu yang tidak bisa ditawar-tawar lagi oleh setiap lembaga pendidikan, terlebih lagi lembaga pendidikan Islam. Optimalisasi kecerdasan spiritual anak pun akan sangat tepat dilakukan sedari dini. Sejak dini, Allah SWT sudah menganugerahi anak fitrah untuk beragama.

Raudhatul Athfal (RA) sebagai lembaga pendidikan Islam pada jenjang Pendidikan Anak Usia Dini (PAUD) memiliki peran yang sangat strategis dalam optimalisasi kecerdasan spiritual anak. Namun sayangnya tidak semua RA memfokuskan penyelenggaraan layanan PAUD pada optimalisasi kecerdasan spiritual anak. Masih mudah ditemui RA yang memfokuskan penyelenggaraan layanan PAUD pada optimalisasi kecerdasan intelektual anak. Indikatornya seperti anak difokuskan untuk memiliki kemampuan membaca, menulis, dan berhitung 
(calistung) serta agama pun diajarkan melalui hafalan-hafalan dalam bentuk nyanyian, yel-yel, dan tepuk-tepuk. Bukankah ajaran agama itu untuk dipraktekkan?

Untuk mengarahkan agar RA memfokuskan diri pada optimalisasi kecerdasan spiritual anak, maka manajemen layanan PAUD di RA juga harus fokus pada optimalisasi kecerdasan spiritual anak usia dini. Bentuk layanan PAUD di RA bukan hanya mencangkup kegiatan pembelajaran dan pengasuhan saja tetapi juga mencangkup kegiatan pembiasaan. Optimalisasi kecerdasan spiritual anak sejak dini akan sangat tepat jika dilakukan melalui kegiatan pembiasaan. Ini karena dengan kegiatan pembiasaan anak bukan hanya akan mendapatkan pengetahuan tentang kebaikan-kebaikan tetapi juga mendapatkan kesempatan untuk mempraktekkan kebaikan-kebaikan.

Untuk memastikan agar dalam kegiatan pembiasaan anak bisa mendapatkan pengetahuan tentang kebaikan-kebaikan dan mempraktikkan kebaikan-kebaikan tersebut, maka kegiatan pembiasaan harus dikembangkan secara efektif dan efisien. Sedangkan untuk memastikan agar pengembangan kegiatan pembiasaan dapat berlangsung efektif dan efisien maka perlu diadopsi Total Quality Management (TQM) di dalamnya. Pada tulisan ini dikaji tentang bagaimana pengembangan kegiatan pembiasaan berbasis TQM di RA. Ekspektasinya tulisan ini dapat menjadi guideline bagi RA dalam menyelenggarakan kegiatan pembiasaan untuk mengoptimalkan kecerdasan spiritual anak.

\section{B. HASIL DAN PEMBAHASAN}

\section{Kegiatan Pembiasaan bagi Anak Usia Dini}

Pembiasaan berasal dari kata biasa. Pada kamus besar bahasa Indonesia disebutkan bahwa biasa memiliki makna umum, seperti sedia kala, sesuatu yang sudah merupakan hal yang tidak terpisahkan dari kehidupan sehari-hari, dan sudah seringkali dilakukan. Kata kerjanya adalah membiasakan yang berarti menjadikan lazim dan menjadikan terbiasa. Kata bendanya adalah kebiasaan yang berarti sesuatu yang sudah terbiasa dilakukan. Sedangkan kata sifatnya adalah terbiasa yang berarti sudah biasa (Alwi, dkk, 2002: 146).

Imbuhan "pem-“" dan "-an" pada kata biasa mengarah pada suatu proses, yaitu proses untuk membuat seseorang terbiasa untuk melakukan sesuatu. Jadi secara istilah kegiatan pembiasaan dapat diartikan sebagai upaya yang dilakukan oleh seseorang atau sekelompok orang untuk membiasakan seseorang maupun sekelompok orang untuk melakukan suatu aktivitas. 
Dalam konteks pendidikan, pembiasaan kemudian menjadi salah satu metode yang digunakan dalam mendidik anak. Abdullah Nashih Ulwan (2012: 543) mengungkapkan bahwa metode pembiasaan sangat tepat digunakan untuk menguatkan keimanan dan akhlak anak. Ini berarti Metode pembiasaan merupakan salah satu metode yang sangat tepat untuk digunakan dalam optimalisasi kecerdasan spiritual anak.

Abdullah Nashih Ulwan (2012: 543) menjelaskan bahwa sejak lahir anak sudah memiliki fitrah untuk beragama. Hal itu menjadikan anak harus dibiasakan untuk melakukan perilaku-perilaku yang baik sesuai dengan ajarannya agar kuat keimanan dan ketaqwaannya sedari dini. Jika orang tua maupun guru membiasakan anak untuk melakukan kebaikankebaikan maka anak akan berkembang menjadi baik dan selamat di dunia dan akherat. Dapatlah dikatakan pengajaran tentang kebaikan menabur benih ke tengah lautan jika dilaksanakan tanpa kegiatan pembiasaan (Mursidin, 2011: 69).

Dalam konteks keluarga, kegiatan pembiasaan yang dilakukan oleh orang tua terhadap anak-anaknya dapat menjadikan lingkungan keluarga memiliki iklim yang kondusif bagi perkembangan agama dan moral anak. Lingkungan keluarga pun menjadi basis dalam optimalisasi kecerdasan spiritual anak (Zubaedi, 2012: 144).

Namun sayangnya tidak semua orang tua bisa menjadi pendidik yang mampu membiasakan anak-anaknya untuk berbuat kebaikan secara optimal di lingkungan keluarganya. Umumnya orang tua menyerahkan pelaksanaan kegiatan pembiasaan untuk mengoptimalkan kecerdasan spiritual anak pada lembaga-lembaga pendidikan seperti Raudhatul Athfal (RA).

Jika RA dapat menyelenggarakan kegiatan pembiasaan yang efektif dan efisien bagi anak usia dini, maka hal itu dapat menjadikan lingkungan RA memiliki iklim yang kondusif bagi perkembangan agama dan moral anak. Ada tiga bentuk kegiatan pembiasaan yang dapat diselenggarakan oleh guru RA untuk anak usia dini, yaitu:

Pembiasaan rutin

Pembiasaan rutin merupakan kegiatan yang dilakukan oleh guru RA untuk membiasakan anak usia dini melakukan kebaikan-kebaikan secara terjadwal maupun terprogram. Misalnya kegiatan penyambutan kedatangan anak setiap pagi, kegiatan berdoa sebelum belajar, kegiatan berwudlu sebelum belajar, kegiatan tadarus sebelum belajar, kegiatan sholat dhuha dan sholat dhuhur, berdoa sebelum dan sesudah makan, cuci tangan 
sebelum dan sesudah makan, kegiatan berpamitan dan bersalaman dengan guru sebelum pulang, dan lain sebagainya.

Kegiatan-kegiatan bagi anak usia dini dalam pembiasaan rutin merupakan perbuatanperbuatan sederhana yang berhubungan dengan kegiatan sehari-hari anak (Kertamuda, 2015: 69). Perbuatan-perbuatan sederhana tersebut dibiasakan untuk dilakukan secara bertahap. Hal ini sesuai dengan karakteristik anak usia dini yang belajar secara bertahap mengikuti tahapan perkembangan berpikirnya (Hasnida, 2016: 42).

a. Pembiasaan spontan

Pembiasaan spontan merupakan kegiatan yang dilakukan oleh guru RA untuk membiasakan anak usia dini melakukan kebaikan-kebaikan secara spontanitas. Ini berarti kegiatan pembiasaan spontan dilakukan menyesuaikan dengan suatu kondisi dan situasi yang melingkupi aktivitas keseharian anak usia dini. Bentuk-bentuk kegiatan pembiasaan spontan yang dapat dilakukan oleh guru RA antara lain:

1) Pemberian hadiah

Pemberian hadiah merupakan upaya yang dilakukan oleh guru RA untuk memberikan sesuatu yang menyenangkan pada anak sebagai implikasi dari perilaku baik yang dilakukan anak. Hadiah tersebut bisa berupa materi maupun non materi. Sebaiknya hadiah yang diberikan berupa hadiah non materi seperti memberikan pujian atas keberhasilan anak dalam berperilaku baik. Secara psikologis pemberian pujian pada seorang anak dapat menjadikannya merasa senang, terdorong, dan bersemangat untuk melakukan kebaikan-kebaikan dengan lebih baik lagi. Guru RA pun diharapkan untuk tidak pelit dalam memuji anak (Prameswari, 2016: 22).

2) Pemberian hukuman

Pemberian hukuman merupakan upaya yang dilakukan oleh guru RA untuk memberikan sesuatu yang tidak menyenangkan pada sebagai implikasi dari perilaku buruk yang dilakukan anak. Hukuman yang diberikan bisa berupa hukuman fisik maupun hukuman psikis. Hukuman fisik bisa berlaku jika anak sudah berusia sepuluh tahun. Dasarnya adalah Hadis Nabi Muhammad Saw yang menyatakan bahwa "Perintahkanlah anakmu untuk mengerjakan solat di usia tujuh tahun, dan pukullah jika ia tidak melakukan solat di usia sepuluh tahun".

Jadi dalam mendidik anak usia dini, guru RA dilarang memberikan hukuman fisik pada anak. Hukuman yang diberikan kepada anak usia dini berupa hukuman psikis. 
Misalnya anak tidak diberikan kesempatan untuk melakukan hal-hal yang menyenangkan baginya, anak dipisahkan tempat duduknya dari teman-temannya, dan lainnya. Hukuman itu diberikan kepada anak agar anak jera dan tidak mengulangi perilaku buruknya lagi,

3) Pemberian nasehat

Pemberian nasehat merupakan upaya yang dilakukan oleh guru RA kepada anak untuk memberikan pesan-pesan positif kepada anak. Ada dua tujuan dari pemberian nasehat kepada anak. Pertama, untuk memberikan pengetahuan tentang perilaku baik dan perilaku buruk pada anak sehingga anak bisa membedakannya dan mampu menjelaskan dampak-dampak dari perilaku baik dan perilaku buruk tersebut.Kedua, untuk memberikan motivasi atau dorongan kepada anak agar mau dan mampu melakukan perilaku-perilaku baik.

Pemberian nasehat dapat dilakukan secara langsung ketika anak menampilkan perilaku baik dan perilaku buruk. Bisa juga disampaikan oleh guru RA di dalam kegiatan pembelajaran melalui pemberian cerita-cerita maupun kisah-kisah dengan memanfaatkan berbagai media edukatif, seperti boneka jari, boneka tangan, wayang kertas, dan lainnya.

b. Pembiasaan keteladanan

Kegiatan pembiasaan untuk mengoptimalkan kecerdasan spiritual anak akan lebih efektif dilakukan jika dilengkapi dengan pembiasaan keteladanan (Hidayat, 2013: 6.33). Pembiasaan keteladanan adalah upaya pemberian contoh perilaku baik kepada anak yang dilakukan oleh guru RA secara konsisten agar anak juga melakukan perilaku baik seperti yang dicontohkannya. Nabi Muhammad SAW sukses menyempurnakan akhlak umatnya dengan memberikan keteladanan kepada umatnya. Bahkan Allah SWT menyebutkan bahwa Nabi Muhammad adalah suri teladan yang paling baik.

Kegiatan pembiasaan bagi anak usia dini yang diselenggarakan oleh guru RA sebagai salah satu bentuk layanan PAUD dilakukan dengan prinsip interaktif, inspiratif, menyenangkan, menantang, dan motivasi (Adisusilo, 2013: 87). Prinsip interaktif mengandung makna bahwa kegiatan pembiasaan bukan hanya sekedar dilakukan untuk memberikan pengetahuan tentang perilaku baik kepada anak secara langsung, tetapi juga mengatur lingkungan yang dapat menstimulasi anak untuk melakukan perilaku baik. Dari hal ini maka dalam kegiatan pembiasaan perlu dilakukan kegiatan pengkondisian, baik 
pengkondisian sarana dan prasarananya maupun pengkondisian perilaku anak itu sendiri berdasarkan aturan yang berlaku di RA.

Prinsip inspiratif memiliki makna bahwa kegiatan pembiasaan yang dilakukan di lingkungan RA harus mampu menginspirasi orang tua untuk melaksanakan kegiatan pembiasaan yang sama di lingkungan keluarga. Dari hal ini kemudian muncul sinkronisasi kegiatan pembiasaan di RA dengan di lingkungan keluarga. Jika kegiatan pembiasaan di lingkungan RA dan lingkungan keluarga maka keberhasilan dalam mengoptimalkan kecerdasan spiritual anak dapat dicapai secara efisien.

Prinsip menyenangkan mengandung arti bahwa kegiatan pembiasaan yang diselenggarakan oleh guru RA untuk anak usia dini tidak boleh membebani anak, sesuai dengan tahap tumbuh-kembang anak, serta pelaksanaannya menyesuaikan karakteristik anak usia dini yang gemar bermain.

Prinsip menantang memiliki pengertian bahwa kegiatan pembiasaan yang dilakukan oleh anak usia dini harus dapat menjadikan mereka tertantang untuk melakukan perilaku baik. Misalnya memberikan tantangan kepada anak untuk menjadi muadzin, menjadi imam ketika sholat dhuhur berjamaah, dan lainnya.

Prinsip memotivasi mengandung makna bahwa kegiatan pembiasaan harus mampu memunculkan rasa cinta akan kebaikan (loving the good) pada diri anak sehingga anak termotivasi untuk melakukan kebaikan-kebaikan (acting the good). Tentunya rasa cinta akan kebaikan dapat muncul jika anak memiliki pengetahuan tentang kebaikan (knowing the good).

\section{Hakikat Total Quality Management (TQM) di Raudhatul Athfal (RA)}

Total Quality Management (TQM) jika diterjemahkan ke dalam bahasa Indonesia menjadi Manajemen Mutu Terpadu. Manajemen dapat diartikan sebagai upaya mengelola sumber daya pada suatu organisasi melalui kegiatan perencanaan, pengorganisasian, pergerakkan, dan penilaian untuk mencapai tujuan organisasi. Sedangkan mutu adalah sesuatu (bisa barang maupun jasa) yang memiliki standar, ukuran atau kriteria tertentu yang telah ditetapkan oleh sekelompok orang. Jadi sesuatu disebut bermutu jika sesuatu tersebut memenuhi kriteria-kriteria yang telah ditentukan. Kemudian total dapat diartikan sebagai keadaaan di mana setiap orang yang berada dalam suatu organisasi harus terlibat dalam upaya melakukan perbaikan berkelanjutan (Sallis, 2010: 74). 
Vincent Gaspersz (2008: 5) mendefinisikan TQM sebagai suatu cara untuk meningkatkan performansi secara terus-menerus (continuous performance improvement) pada setiap proses dalam setiap area fungsional dari suatu organisasi dengan menggunakan sumber daya manusia dan modal yang tersedia.

Menurut penulis, TQM di RA dapat diartikan sebagai strategi perbaikan berkelanjutan untuk mencapai tujuan RA melalui kegiatan perencanaan, pengorganisasian, pergerakkan, dan penilaian sesuai dengan kriteria-kriteria yang telah disepakati dengan melibatkan peran serta seluruh warga RA.

Implementasi TQM di RA dipahami sebagai unit layanan jasa. Anak, orang tua dan masyarakat menjadi pelanggan eksternal yang harus dilayaninya dengan baik. Guru RA dan staf menjadi pelanggan internal yang harus dilayaninya dengan baik pula. Ada sepuluh karakteristik TQM, antara lain:

a. Fokus pada pelanggan, baik pelanggan eksternal maupun pelanggan internal. Kepuasan pelanggan pun menjadi hal yang harus didapat oleh RA yang menerapkan TQM. Hubungan baik dengan pelanggan (keeping close to the costumer) harus dilakukan untuk mewujudkan kepuasan pelanggan.

b. Memiliki obsesi yang tinggi terhadap mutu. Setiap kegiatan PAUD diarahkan untuk memenuhi standar mutu PAUD secara bertahap.

c. Menggunakan pendekatan ilmiah dalam pengambilan keputusan dan pemecahan masalah. Pendekatan yang digunakan seperti analisis SWOT (Strengths, Weakness, Opportunities, and Threatment/Kekuatan, Kelemahan, Peluang, dan Tantangan).

d. Memiliki komitmen jangka panjang. Komitmen tersebut ditunjukkan dengan kepemilikan rencana jangka panjang.

e. Mencapai tujuan dengan kerja tim. Kata "total" pada TQM menunjukkan adanya kerja kolaboratif dari seluruh SDM di RA. Ini menunjukkan bahwa tujuan RA dicapai melalui kerja tim.

f. Memperbaiki proses secara berkelanjutan. Istilahnya adalah continuous improvement. Sallis (2010: 76) mengungkapkan bahwa TQM dapat dipahami sebagai filosofi perbaikan tanpa henti hingga tujuan organisasi dapat dicapai dan dengan melibatkan segenap komponen dalam organisasi tersebut.

g. Menyelenggarakan pendidikan dan pelatihan bagi SDM RA. SDM RA dalam implementasi TQM merupakan warga pembelajar. Mereka menjadi pendidik dan 
pengajar sekaligus pembelajar. Tidak ada istilah untuk berhenti belajar bagi SDM RA. Kegiatan belajar tersebut dilakukan untuk meningkatkan kompetensi SDM RA (dalam hal ini adalah guru RA dan staf) dalam menyelenggarakan layanan PAUD.

h. Memberikan kebebasan yang terkendali. SDM RA dalam implementasi TQM diberi kewenangan untuk bekerja sesuai dengan ide-idenya. Tugas kepala RA adalah memfasilitasi mereka untuk mewujudkan ide-idenya dan mengendalikan mereka untuk mewujudkan ide-idenya pada pencapaian visi RA, bukan visi pribadi. Ini merupakan implikasi dari diberlakukannya pola organisasi dari bawah ke atas (bottom up).

i. Memiliki kesatuan yang terkendali. Ini merupakan implikasi dari praktik kerja tim pada RA yang menerapkan TQM. Guru RA bukan hanya bekerjasama dengan guru RA tetapi juga harus bekerjasama dengan staf.

j. Melibatkan masyarakat dalam meraih tujuan RA. Pelibatan masyarakat tersebut bukan hanya ketika melaksanakan layanan PAUD saja, tetapi juga ketika merumuskan rencana penyelenggaraan layanan PAUD. Ini harus dilakukan karena pada dasarnya penyelenggaraan layanan PAUD harus sesuai dengan keinginan dan kebutuhan masyarakat(Umiarso dan Gojali, 2010: 136).

Jika suatu RA hendak menerapkan TQM dalam penyelenggaraan layanan PAUD maka harus memperhatikan dasar-dasar TQM berikut ini:

a. Komitmen pada perubahan

RA yang menerapkan TQM dengan berbagai program mutunya harus memiliki komitmen untuk berubah, yaitu berubah ke arah yang lebih baik dengan melakukan dua upaya. Pertama, melakukan perbaikan berkelanjutan (continuous improvement). Kedua, melakukan sesuatu di awal dengan baik (right first time, right everytime).

b. Pemahaman yang jelas tentang kondisi yang ada.

Ini karena banyak kegagalan dalam melaksanakan program mutu disebabkan oleh tidak mengenali apa yang sebenarnya menjadi kelebihan dan kelemahan RA serta peluang dan tantangan RA. Kejelasan kondisi pada RA dapat menjadikan SDM RA memiliki strategi yang jitu untuk mencapai tujuan RA.

c. Mempunyai visi yang jelas terhadap masa depan.

Perubahan yang hendak dituju pada RA harus mengarah pada visi RA. Visi adalah kondisi ideal yang harus terjadi pada RA. Visi juga dapat diartikan sebagai 
tujuan puncak yang dimiliki oleh RA. Visi dapat pula diartikan sebagai pandangan jauh ke depan, itulah sebab visi RA selalu dikaitkan dengan masa depan RA.

d. Mempunyai rencana yang jelas.

RA menyusun rencana penyelenggaraan layanan PAUD yang jelas dengan mengacu pada visi. Rencana menjadi pegangan dalam proses pelaksanaan program mutu. Pelaksanaan program mutu dipengaruhi oleh faktor internal dan eksternal yang selalu berubah-ubah. Rencana juga harus selalu relevan dan up to date dengan perubahan-perubahan (Musbikin, 2013: 94). Dengan demikian dapatlah dikatakan rencana yang disusun harus sesuai dengan keinginan dan kebutuhan masyarakat serta tantangan zaman.

Beberapa program mutu yang dapat diterapkan di RA adalah sebagai berikut:

a. Membuat visi, misi, nilai-nilai dan tujuan RA. Visi merupakan tujuan puncak RA. Misi mendeskripsikan garis-garis besar yang harus dilakukan untuk meraih visi. Nilai-nilai adalah prinsip-prinsip yang menjadi dasar dalam menyelenggarakan layanan PAUD untuk mencapai visi. Sedangkan tujuan menggambarkan sasaran yang hendak dicapai.

b. Menetapkan standar mutu RA. Secara internal, suatu RA bisa membuat standar mutu sendiri dengan mengacu pada dua hal. Pertama, standar nasional PAUD yang terdapat dalam Permendikbud RI Nomor 137 Tahun 2014. Kedua, potensi sumber daya yang dimiliki oleh RA.

c. Menetapkan jaminan mutu lulusan RA (quality assurance) berdasarkan visi RA. Jaminan mutu lulusan mendeskripsikan spesifikasi dari kompetensi (kemampuan) yang harus dimiliki oleh lulusan suatu RA.

d. Merumuskan strategi pencapaian jaminan mutu lulusan. Strategi tersebut mendeskripsikan langkah-langkah yang dilakukan untuk membuat anak memiliki kompetensi sesuai dengan jaminan mutu lulusan RA.

e. Menyusun standard operating procedures (SOP) strategi pencapaian jaminan mutu lulusan.SOP merupakan dokumen yang menjabarkan aktivitas operasional yang dilaksanakan sehari-hari dengan tujuan agar pekerjaan tersebut dilaksanakan secara benar, tepat, dan konsisten untuk menghasilkan produk (barang ataupun jasa) sesuai dengan standar (kriteria) yang telah ditetapkan (Tathagati, 2014: 1).

f. Melaksanakan strategi pencapaian jaminan mutu lulusan sesuai dengan SOP. Dapatlah dikatakan SOP menjadi petunjuk operasional dalam melaksanakan strategi. 
g. Mendesain instrumen penilaian untuk mengontrol implementasi strategi (quality qontrol). Ini dilakukan sebagai upaya untuk mengontrol pelaksanaan strategi untuk memastikan bahwa strategi tersebut dilaksanakan sesuai dengan SOP. Ekspektasinya kesesuaian tersebut dapat mengarah pada pencapaian jaminan mutu lulusan RA. Kontrol mutu dilakukan bukan hanya pasca proses (setelah strategi dilaksanakan), tetapi juga pada pra proses dan ketika proses berjalan.

\section{Desain Kegiatan Pembiasaan Berbasis TQM untuk Mengoptimalkan}

RA yang memfokuskan layanan PAUD untuk mengoptimalkan kecerdasan spiritual anak usia dini idealnya memfokuskan kegiatan manajemennya pada pembentukan karakter anak usia dini. Langkah pertama yang dilakukan adalah dengan membuat kebijakan RA yang menjadi dasar dalam implementasi pembentukan karakter bagi anak usia dini.

Kebijakan RA dalam implementasi pembentukan karakter bagi anak usia dini tersebut dibuat di level yayasan hingga di level RA. Kebijakan RA di level yayasan dijadikan sebagai dasar dalam membuat kebijakan RA di level RA. Kebijakan RA dalam implementasi pembentukan karakter bagi anak usia dini di level yayasan berbentuk Surat Keputusan (SK) Ketua Yayasan.

Kebijakan RA dalam implementasi pembentukan karakter bagi anak usia dini pada level RA dibuat oleh manajemen RA bekerja sama dengan komite sekolah. Hal ini ditujukan agar kebijakan RA benar-benar mengakomodir keinginan dan kebutuhan wali murid sebagai pelanggan ekstenal RA. Selain itu, harapannya komite sekolah juga ikut mensosialisasikan kebijakan RA dan ikut mensukseskan dalam implementasi kebijakan tersebut. Kebijakan RA dalam implementasi pembentukan karakter bagi anak usia dini di level RA berbentuk Surat Keputusan (SK) Kepala RA.

Kebijakan RA dalam implementasi pembentukan karakter bagi anak usia dini pada level RA dibuat berdasarkan hasil analisis SWOT yang dilakukan oleh manajemen RA. Analisis SWOT tersebut dapat dibuat dengan menggunakan tabel instrumen analisis SWOT sebagai berikut: 
Tabel 1

Analisis SWOT Raudhatul Athfal

\begin{tabular}{|c|c|}
\hline \multicolumn{2}{|c|}{ Tabel Analisis SWOT Raudhatul Athfal (RA) } \\
\hline Kekuatan & Kelemahan \\
\hline 1. .......... & 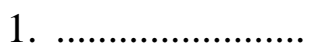 \\
\hline 2. ........................ & 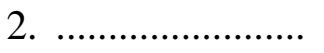 \\
\hline 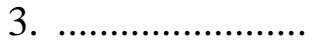 & 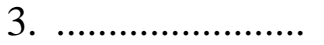 \\
\hline 4. Dan seterusnya & Dan seterusnya \\
\hline Peluang & Tantangan \\
\hline $1 . \ldots \ldots \ldots \ldots \ldots \ldots \ldots \ldots$ & 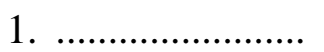 \\
\hline 2. .......................... & 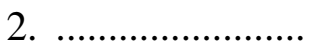 \\
\hline 3. ......................... & 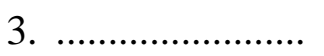 \\
\hline Dan seterusnya & Dan seterusnya \\
\hline
\end{tabular}

Berdasarkan analisis SWOT dan kebijakan RA maka disusunlah visi, misi, tujuan, dan nilai-nilai RA yang fokus pada pembentukan karakter anak usia dini. Misalnya berikut ini:

Tabel 2

Visi dan Misi RA Ar Rahman

\begin{tabular}{|l|}
\hline \multicolumn{1}{|c|}{ RA Ar-Rahman } \\
\hline Visi : \\
"Melahirkan Generasi Qur'ani yang Cerdas Spiritual dan Cerdas Intelektual pada \\
Tahun 2023" \\
\hline Misi : \\
1. Meningkatkan profesionalisme guru RA untuk menghasilkan layanan PAUD \\
yang bermutu. \\
2. Memanfaatkan sarana dan prasarana RA untuk menyelenggarakan layanan \\
PAUD yang bermutu. \\
3. Menyelenggaraan layanan PAUD yang fokus pada pembentukan karakter anak \\
usia dini. \\
4. Menyelenggarakan layanan PAUD yang kredibel dan akuntabel. \\
5. Menjalin relasi dengan masyarakat untuk kepentingan penyelenggaraan layanan \\
PAUD yang bermutu. \\
Tujuan : \\
1. Menjadi RA yang profesional dalam menyelenggarakan layanan PAUD. \\
2. Menjadi RA yang memiliki sarana dan prasarana belajar sesuai dengan standar \\
nasional PAUD. \\
3. Melahirkan anak usia dini yang berkarakter. \\
4. Menjadi RA yang dipercaya oleh masyarakat. \\
5. Menjadi RA yang memiliki jaringan kerja sama dengan pihak eksternal dalam \\
menyelenggarakan layanan PAUD yang bermutu. \\
Nilai-nilai :
\end{tabular}


1. Bekerja adalah ibadah.

2. Indahnya kebersamaan saat bekerja.

3. Right first time, right everytime.

4. Anak adalah amanah dari Allah SWT.

5. Kepuasan wali murid adalah keberhasilan lembaga.

Jaminan mutu lulusan RA dibuat berdasarkan visi RA yang fokus pada pembentukan karakter anak usia dini. Implikasi dari hal itu adalah jaminan mutu lulusan RA harus mendeskripsikan spesifikasi kompetensi yang hendak dimunculkan pada anak. Berikut adalah contoh jaminan mutu lulusan RA Ar-Rahman yang dirumuskan berdasarkan visi RA Ar-Rahman:

Tabel 3

Kompetensi Lulusan Anak RA Ar Rahman

\begin{tabular}{|c|c|c|}
\hline No & Kompetensi & Indikator \\
\hline 1. & $\begin{array}{l}\text { Mampu melaksanakan } \\
\text { thoharoh. }\end{array}$ & $\begin{array}{l}\text { a. Anak mampu mencuci tangan sebelum } \\
\text { dan sesudah makan. } \\
\text { b. Anak mampu BAK dan BAB sesuai adab } \\
\text { Islam. } \\
\text { c. Anak mampu berwudlu. } \\
\text { d. Anak mampu mandi sesuai dengan adab } \\
\text { Islam. }\end{array}$ \\
\hline 2. & $\begin{array}{l}\text { Mampu melaksanakan } \\
\text { ibadah }\end{array}$ & $\begin{array}{l}\text { a. Anak mampu melaksanakan sholat. } \\
\text { b. Anak mampu melakukan manasik haji. } \\
\text { c. Anak mampu berbagi dengan sesama. }\end{array}$ \\
\hline 3. & $\begin{array}{l}\text { Mampu bersikap mandiri } \\
\text { dan bertanggungjawab. }\end{array}$ & $\begin{array}{l}\text { a. Anak mampu menempatkan sepatu dan } \\
\text { tas di tempatnya. } \\
\text { b. Anak mampu menjaga alat tulisnya. } \\
\text { c. Anak mampu membereskan tempat } \\
\text { makannya. } \\
\text { d. Anak mampu menjaga kebersihan diri } \\
\text { dan lingkungannya. }\end{array}$ \\
\hline 4. & Mampu mematuhi aturan. & $\begin{array}{l}\text { a. Anak mampu mengantri. } \\
\text { b. Anak mampu berpakaian sesuai dengan } \\
\text { jadwal seragam sekolah. } \\
\text { c. Anak mampu mengambil giliran dalam } \\
\text { bermain. }\end{array}$ \\
\hline 5. & $\begin{array}{l}\text { Mampu berkomunikasi } \\
\text { dengan orang lain. }\end{array}$ & $\begin{array}{l}\text { a. Anak mampu berpamitan kepada orang } \\
\text { tua dan guru. } \\
\text { b. Anak mampu mengucapkan salam, } \\
\text { menyapa, dan bersalaman. } \\
\text { c. Anak mampu berkata tolong, maaf, dan } \\
\text { terima kasih. }\end{array}$ \\
\hline
\end{tabular}




\begin{tabular}{|c|l|l|l|}
\hline 6. & $\begin{array}{c}\text { Mampu menghafal surat- } \\
\text { surat pendek dan doa sehari- } \\
\text { hari. }\end{array}$ & $\begin{array}{l}\text { a. Anak mampu membaca IQRA dan al- } \\
\text { Qur'an. } \\
\text { b. Anak mampu menghafal surat-surat } \\
\text { pendek pada Juz 'Amma. } \\
\text { c. Anak mampu melafadzkan doa sehari- } \\
\text { hari. }\end{array}$ \\
\hline 7. & $\begin{array}{l}\text { Mampu mengenal huruf dan } \\
\text { lambang bilangan. }\end{array}$ & $\begin{array}{l}\text { a. Anak mampu mengenal huruf hijaiyah. } \\
\text { b. Anak mampu mengenal huruf latin. } \\
\text { c. Anak mampu mengenal bilangan. }\end{array}$ \\
\hline 8. & $\begin{array}{l}\text { Mampu mengoperasikan } \\
\text { komputer }\end{array}$ & $\begin{array}{l}\text { a. Anak mampu mengetik identitas diri } \\
\text { dalam program microsoft word. } \\
\text { b. Anak mampu bermain game edukatif } \\
\text { dalam personal computer. }\end{array}$ \\
\hline
\end{tabular}

Kemudian berbagai strategi harus dirumuskan oleh manajemen RA bekerjasama dengan guru RA untuk mencapai indikator dalam jaminan mutu lulusan di atas. Contohnya adalah berikut ini:

Tabel 4

Rumusan Strategi Pembelajaran di RA Ar Rahman

\begin{tabular}{|c|c|}
\hline & \\
\hline $\begin{array}{l}\text { esudah makan. } \\
\text { BAK dan BAB } \\
\text { lam. } \\
\text { berwudlu. } \\
\text { u mandi sesuai } \\
\text { slam. }\end{array}$ & $\begin{array}{l}\text { dci tangan sebelum dan } \\
\text { ar dan bermain. } \\
\text { n melakukan BAK dan BAB } \\
\text { lam. } \\
\text { erwudlu sebelum sholat dan } \\
\text { an mandi sesuai adab Islam } \\
\text { kuti kegiatan renang. }\end{array}$ \\
\hline $\begin{array}{l}\text { 1. Anak mampu melaksanakan } \\
\text { sholat. } \\
\text { 2. Anak mampu melakukan } \\
\text { manasik haji. } \\
\text { 3. Anak mampu berbagi dengan } \\
\text { sesama. }\end{array}$ & $\begin{array}{l}\text { n untuk sholat. } \\
\text { elakukan manasik haji di } \\
\text { tkan dengan aktivitas- } \\
\text { kemasyarakatan. }\end{array}$ \\
\hline $\begin{array}{l}\text { 1. Anak mampu menempatkan } \\
\text { sepatu dan tas di tempatnya. } \\
\text { 2. Anak mampu menjaga alat } \\
\text { tulisnya. } \\
\text { 3. Anak mampu membereskan } \\
\text { tempat makannya. } \\
\text { 4. Anak mampu menjaga } \\
\text { kebersihan diri } \\
\text { lingkungannya. }\end{array}$ & $\begin{array}{l}\text { 1. Anak dibiasakan menempatkan sepatu dan } \\
\text { tas di rak sepatu dan tas. } \\
\text { 2. Anak diajarkan melakukan labelisasi pada } \\
\text { barang pribadinya. } \\
\text { 3. Anak melaksanakan makan bersama. } \\
\text { 4. Anak didekatkan dengan aktivitas- } \\
\text { aktivitas bersih diri dan bersih lingkungan }\end{array}$ \\
\hline $\begin{array}{l}\text { 1. Anak n } \\
\text { 2. Anak } n\end{array}$ & untuk mau \\
\hline
\end{tabular}




\begin{tabular}{|c|c|}
\hline $\begin{array}{l}\text { deng } \\
\text { 3. Anak } \\
\text { dalan }\end{array}$ & $\begin{array}{l}\text { 2. Anak diberi jadwal pemakaian seragam } \\
\text { sekolah. } \\
\text { 3. Anak melakukan kegiatan bermain secara } \\
\text { kolektif. }\end{array}$ \\
\hline $\begin{array}{l}\text { 1. Anak mampu berpamitan } \\
\text { kepada orang tua dan guru. } \\
\text { 2. Anak mampu mengucapkan } \\
\text { salam, menyapa, dan } \\
\text { bersalaman. } \\
\text { 3. Anak mampu berkata tolong, } \\
\text { maaf, dan terima kasih. }\end{array}$ & $\begin{array}{l}\text { 1. Anak dibiasakan berpamitan kepada orang } \\
\text { tua dan guru. } \\
\text { 2. Anak dibudayakan untuk mengucapkan } \\
\text { salam, sapa, dan bersalaman. } \\
\text { 3. Anak dibiasakan untuk berkata tolong } \\
\text { ketika meminta bantuan, mengucapkan } \\
\text { maaf jika berbuat salah, dan berkata terima } \\
\text { kasih setelah ditolong. }\end{array}$ \\
\hline $\begin{array}{l}\text { In. } \\
\text { membaca IQRA } \\
\text { pada Juz 'Amma. } \\
\text { u melafadzkan doa }\end{array}$ & $\begin{array}{l}\text { diajak melakukan murojaah al- } \\
\text { an. }\end{array}$ \\
\hline $\begin{array}{l}\text { 1. Anak mampu mengenal huruf } \\
\text { hijaiyah. } \\
\text { 2. Anak mampu mengenal huruf } \\
\text { latin. } \\
\text { 3. Anak mampu mengenal } \\
\text { bilangan. }\end{array}$ & $\begin{array}{l}\text { berbanasa Arab dan berbanasa Inggri } \\
\text { secara sederhana. }\end{array}$ \\
\hline
\end{tabular}

Setelah strategi-strategi untuk mencapai indikator dalam jaminan mutu lulusan RA dirumuskan barulah pihak manajemen RA dan guru RA menentukan bentuk kegiatan pembiasaan rutin bagi anak usia dini. Dapatlah dikatakan, kegiatan pembiasaan rutin dilakukan untuk mencapai indikator. Ketercapaian indikator akan mengarah pada ketercapaian kompetensi. Ketercapaian kompetensi akan mengarah pada ketercapaian jaminan mutu lulusan. Ketercapaian jaminan mutu lulusan akan mewujudkan visi RA.

Berikut adalah contoh bentuk kegiatan pembiasaan rutin pada RA Ar-Rahman yang disusun berdasarkan strategi yang telah dirumuskan:

Tabel 5

Rumusan Strategi Pembelajaran di RA Ar Rahman

\begin{tabular}{|c|c|c|}
\hline Strategi Pelaksanaan & $\begin{array}{l}\text { Bentuk Kegiatan } \\
\text { Pembiasaan }\end{array}$ & Frekuensi Pelaksanaan \\
\hline $\begin{array}{l}\text { 1. Anak mencuci tangan } \\
\text { sebelum dan sesudah belajar } \\
\text { dan bermain. }\end{array}$ & $\begin{array}{l}\text { Pembiasaan Cuci } \\
\text { Tangan }\end{array}$ & Setiap hari \\
\hline $\begin{array}{l}\text { 2. Anak diajarkan melakukan } \\
\text { BAK dan BAB sesuai adab }\end{array}$ & Toilet training & Satu bulan sekali \\
\hline
\end{tabular}




\begin{tabular}{|c|c|c|}
\hline $\begin{array}{l}\text { Islam. } \\
\text { 3. Anak diajak berwudlu } \\
\text { sebelum sholat dan } \\
\text { murojaah. } \\
\text { 4. Anak diajarkan mandi } \\
\text { sesuai adab Islam setelah } \\
\text { mengikuti kegiatan renang. }\end{array}$ & $\begin{array}{l}\text { Pembiasaan } \\
\text { berwudlu } \\
\text { Pembiasaan mandi } \\
\text { bersih }\end{array}$ & $\begin{array}{l}\text { Satu bulan sekali setelah } \\
\text { melakukan } \\
\text { renang }\end{array}$ \\
\hline $\begin{array}{l}\text { 1. Anak dibiasakan untuk } \\
\text { sholat. } \\
\text { 2. Anak diajak melakukan } \\
\text { manasik haji di bulan } \\
\text { Dzulhijah. } \\
\text { 3. Anak didekatkan dengan } \\
\text { aktivitas-aktivitas sosial } \\
\text { kemasyarakatan. }\end{array}$ & $\begin{array}{l}\text { Pembiasaan sholat } \\
\text { dhuha dan dhuhur } \\
\text { Manasik haji }\end{array}$ & $\begin{array}{l}\text { Setiap hari } \\
\text { Satu tahun sekali }\end{array}$ \\
\hline $\begin{array}{l}\text { 1. Anak dibiasakan } \\
\text { menempatkan sepatu dan } \\
\text { tas di rak sepatu dan tas. } \\
\text { 2. Anak diajarkan melakukan } \\
\text { labelisasi pada barang } \\
\text { pribadinya. } \\
\text { 3. Anak melaksanakan makan } \\
\text { bersama. } \\
\text { 4. Anak didekatkan dengan } \\
\text { aktivitas-aktivitas bersih diri } \\
\text { dan bersih lingkungan }\end{array}$ & $\begin{array}{l}\text { Pembiasaan makan } \\
\text { bersama } \\
\text { Pembiasaan } \\
\text { periksa kuku } \\
\text { Operasi semut }\end{array}$ & $\begin{array}{l}\text { Setiap hari } \\
\text { Satu minggu sekali } \\
\text { Satu minggu sekali }\end{array}$ \\
\hline $\begin{array}{l}\text { 1. Anak dibiasakan untuk mau } \\
\text { mengambil giliran. } \\
\text { 2. Anak diberi jadwal } \\
\text { pemakaian } \\
\text { sekolah. } \\
\text { 3. Anak melakukan kegiatan } \\
\text { bermain secara kolektif. }\end{array}$ & $\begin{array}{l}\text { Pengawalan } \\
\text { antrian } \\
\text { Jadwal pemakaian } \\
\text { seragam } \\
\text { Pagi ceria }\end{array}$ & $\begin{array}{l}\text { Setiap hari } \\
\text { Setiap hari }\end{array}$ \\
\hline $\begin{array}{l}\text { 1. Anak dibiasakan berpamitan } \\
\text { kepada orang tua dan guru. } \\
\text { 2. Anak dibudayakan untuk } \\
\text { mengucapkan salam, sapa, } \\
\text { dan bersalaman. } \\
\text { 3. Anak dibiasakan untuk } \\
\text { berkata tolong ketika } \\
\text { meminta bantuan, }\end{array}$ & $\begin{array}{r}\text { Pembiasaan } \\
\text { penyambutan } \\
\text { Pembiasaan } \\
\text { penyambutan }\end{array}$ & Setiap hari \\
\hline
\end{tabular}




\begin{tabular}{|l|l|l|}
\hline $\begin{array}{l}\text { mengucapkan maaf jika } \\
\text { berbuat salah, dan berkata } \\
\text { terima kasih setelah } \\
\text { ditolong. }\end{array}$ & TOMAT & \\
\hline $\begin{array}{l}\text { 1. Anak diajak melakukan } \\
\text { murojaah al-Qur'an. }\end{array}$ & $\begin{array}{c}\text { Murojaah al- } \\
\text { Qur'an }\end{array}$ & Setiap hari \\
$\begin{array}{l}\text { 2. Anak mengikuti program } \\
\text { tahfidz Qur'an. }\end{array}$ & Satu minggu sekali \\
$\begin{array}{l}\text { 3. Anak mempraktekkan doa } \\
\text { sehari-hari di lingkungan } \\
\text { sekolah dan keluarga. }\end{array}$ & Setoran & Setiap hari \\
\hline $\begin{array}{l}\text { Anak dikenalkan huruf } \\
\text { hijaiyah dan huruf latin } \\
\text { melalui kegiatan bermain. } \\
\text { Anak dibiasakan melakukan } \\
\text { percakapan berbahasa Arab } \\
\text { dan berbahasa Inggris } \\
\text { secara sederhana. }\end{array}$ & Tebak huruf dan & Setiap hari menjelang \\
(Muhadatsah) & Pendampingan & \\
\hline
\end{tabular}

Setiap kegiatan pembiasaan harus memiliki SOP, di mana SOP tersebut dijadikan sebagai guideline dalam pelaksanaan kegiatan pembiasaan. SOP dapat dibuat secara sederhana oleh manajemen RA. SOP dibuat secara sederhana, tidak perlu terlalu rumit, yang terpenting adalah bisa diaplikasikan secara mudah dan konsisten. Sebelum digunakan alangkah baiknya SOP tersebut diuji-cobakan terlebih dahulu. Dari hasil uji coba dapat dilakukan revisi SOP. Tujuan uji coba tersebut adalah untuk memastikan agar SOP tersebut applicable.

Berikut contoh satu SOP dari satu kegiatan pembiasaan di RA Ar-rahman:

\begin{tabular}{|l|}
\multicolumn{1}{|c|}{ SOP Operasi Semut } \\
\hline 1. Anak berkumpul di depan kelas. \\
2. Anak berbaris secara berbanjar di depan kelas. \\
3. Guru meminta kepada anak untuk berjalan dari depan kelas menuju pintu \\
gerbang sambil memungut sampah yang ditemuinya. \\
4. Anak menaruh sampah pada tempat sampah. \\
5. Guru meminta anak untuk mencuci tangan. \\
6. Anak mengambil antrian untuk mencuci tangan. \\
7. Anak kembali ke ruang kelas dengan tertib. \\
\hline
\end{tabular}

Kegiatan pembiasaan rutin dilaksanakan berdasarkan SOP yang telah dibuat. Dalam pelaksanaannya, kegiatan pembiasaan rutin harus dibarengi dengan pembiasaan spontan 
dan pembiasaan keteladanan. Tujuannya adalah agar setiap indikator pada setiap kompetensi dapat dicapai secara efektif dan efisien.

Sebagai upaya untuk mengontrol kegiatan pembiasaan yang difasilitasi oleh guru RA, kepala RA melaksanakan kegiatan supervisi secara periodik. Ini berarti kegiatan supervisi tidak hanya dilakukan selama satu kali dalam satu semester atau bahkan satu tahun, tetapi dilaksanakan minimal dua kali dalam satu semester. Pada kegiatan supervisi tersebut kepala RA memonitoring apakah kinerja guru RA dalam melaksanakan suatu bentuk kegiatan pembiasaan sudah sesuai dengan SOP atau belum. Jika belum sesuai kemudian dicari penyebabnya, dibicarakan solusinya, dan ditindaklanjuti sebagai upaya untuk melakukan perbaikan berkelanjutan (continuous improvement).

Ada beberapa prinsip yang harus diaktualisasikan oleh manajemen dan guru RA dalam pengembangan kegiatan pembiasaan bagi anak usia dini berbasis TQM, yaitu:

a. Guru RA merupakan ujung tombak dalam keberhasilan pengembangan kegiatan pembiasaan bagi anak usia dini berbasis TQM. Hal itu menjadikan kepala RA harus senantiasa meng-up datekompetensi guru RA.

b. Guru RA harus melaksanakan kegiatan pembiasaan secara kolaboratif. Ini berarti kepala RA harus membentuk dan mendinamisasikan guru RA sebagai tim kerja yang memiliki kesamaan visi.

c. Ide dan dokumen menjadi kekayaan yang paling berharga dalam pengembangan kegiatan pembiasaan bagi anak usia dini berbasis TQM. Ini berarti ide-ide guru RA dalam pengembangan kegiatan pembiasaan bagi anak usia dini harus diakomodir bahkan diwujudkan oleh kepala RA dan juga setiap kegiatan pembiasaan harus didokumentasikan. Dokumentasi tersebut dapat dijadikan sebagai bahan masukan untuk melaksanakan upaya perbaikan secara berkelanjutan dalam pengembangan kegiatan pembiasaan bagi anak usia dini berbasis TQM.

d. Kepuasan wali murid menjadi salah satu fokus dalam pelaksanaan kegiatan pembiasaan anak usia dini. Sebaiknya kepala RA mampu melibatkan wali murid dalam pelaksanaan kegiatan pembiasaan di lingkungan RA maupun di lingkungan keluarga serta menjaga hubungan baik dengan wali murid, masyarakat, dan kedinasan. 


\section{SIMPULAN}

Keberhasilan anak dalam menjalani kehidupan di dunia dan di akherat sangat ditentukan oleh kecerdasan spiritualnya. Hal itu menjadikan RA sebagai lembaga pendidikan Islam harus memfokuskan penyelenggaraan kegiatan PAUD yang mampu mengoptimalkan kecerdasan spiritual anak usia dini. Pembiasaan merupakan suatu kegiatan PAUD yang dipandang dapat dijadikan sebagai strategi untuk mengoptimalkan kecerdasan spiritual anak usia dini.

Agar kecerdasan spiritual pada anak usia dini dapat dioptimalkan melalui kegiatan pembiasaan, maka kegiatan pembiasaan harus dikembangkan secara efektif dan efisien. Efektivitas dan efisiensi dalam pelaksanaan kegiatan pembiasaan tersebut sangat ditentukan oleh kemampuan kepala RA dalam mengelola kegiatan pembiasaan. TQM dapat dijadikan sebagai suatu strategi yang digunakan untuk mengembangkan kegiatan pembiasaan.

Ada delapan langkah dalam pengembangan kegiatan pembiasaan bagi anak usia dini berbasis TQM. Pertama, melakukan analisis SWOT. Kedua, membuat kebijakan RA yang fokus pada pembentukan karakter anak usia dini. Ketiga, merumuskan visi, misi, tujuan, dan nilai-nilai yang fokus pada pembentukan karakter anak usia dini. Keempat, membuat jaminan mutu lulusan RA. Kelima, menentukan strategi pencapaian jaminan mutu lulusan RA. Keenam, menentukan kegiatan pembiasaan untuk mencapai indikator pada setiap kompetensi di jaminan mutu lulusan RA. Ketujuh, membuat SOP setiap bentuk kegiatan pembiasaan. Kedelapan, melakukan kegiatan supervisi untuk memastikan bahwa jalannya kegiatan pembiasaan sesuatu dengan SOP.

\section{DAFTAR PUSTAKA}

Adisusilo, Sutarjo. (2013). Pembelajaran Nilai-Karakter: Konstruktivisme dan VCT sebagai Inovasi Pendekatan Pembelajaran Afektif. Jakarta: Rajawali Press.

Gaspersz, Vincent. (2008). Total Quality Management. Jakarta: Gramedia.

Hasan Alwi, dkk. (2002). Kamus Besar Bahasa Indonesia. Jakarta: Balai Pustaka.

Hasnida. (2016). Panduan Pendidik dalam Mengimplementasikan Kurikulum PAUD 2013. Jakarta: Luxima.

Hidayat, Otib Satibi. (2013). Metode Pengembangan Moral dan Nilai-nilai Agama. Jakarta: Universitas Terbuka.

Kertamuda, Miftahul Achyar. (2015). Golden Age: Strategi Sukses Membentuk Karakter Emas pada Anak Sejak Usia Dini. Jakarta: Gramedia. 
Mursidin. (2011). Moral Sumber Pendidikan: Sebuah Formula Pendidikan Budi Pekerti di Sekolah/Madrasah. Bogor: Ghalia Indonesia.

Musbikin, Imam. (2013). Menjadi Kepala Sekolah yang Hebat. Pekanbaru: Zanafa Publishing.

Prameswari. (2016). Mengasuh Anak dengan Hati: Pedoman Pola Asuh dengan Emosi dan Energi Positif. Yogyakarta: Saufa.

Sallis, Edward. (2010). Total Quality Management in Education: Manajemen Mutu Pendidikan. Yogyakarta: IRCiSoD.

Tathagati, Arini. (2014). Step by Step Membuat SOP. Yogyakarta: Efata Publishing. Ulwan, Abdullah Nashih. (2012). Pendidikan Anak dalam Islam. Solo: Insan Kamil.

Zubaedi. (2012). Desain Pendidikan Karakter: Konsepsi dan Aplikasinya dalam Lembaga Pendidikan. Jakarta: Kencana. 